\title{
Electronic Choke Having High Input-Impedance Buffer and Signal Canceller
}

\begin{abstract}
A. Katsuki, T. Hashimoto, and T. Matsunaga
Faculty of Computer Science and Systems Engineering, Kyushu Inst. of Tech., 680-4 Kawazu, Iizuka-shi, Fukuoka 820-8502, Japan

Communication lines in wire communication systems are usually used as power lines. The AC communication signal and DC supply power are separated at the input part in a powered terminal. Conventional wellknown separators utilize the combined circuits of inductors and capacitors. When the frequency of the signal is at its lowest, the inductance increases, making it necessary to have a large inductor. A conventional electronic choke circuit using transistors has the disadvantage of high power dissipation. Furthermore, the direction of the DC current is limited to unidirectional. Our original communication system consists of powering terminals with low-power DC-DC converters and the terminals they power. The direction of the DC current in the powering terminals is opposite to that in the powered terminals. Therefore, it is preferable to have a bidirectional electronic choke. In this paper, a new low-loss electronic choke with small inductors and amplifiers is proposed. This circuit is composed of a high input-impedance buffer and a signal canceller. Input-impedance and other characteristics are investigated through an experiment and analysis.
\end{abstract}

Key words: electronic choke, dc-dc converter, power supply, wire communication system, signal canceller, transmitter, receiver, powering terminal, powered terminal

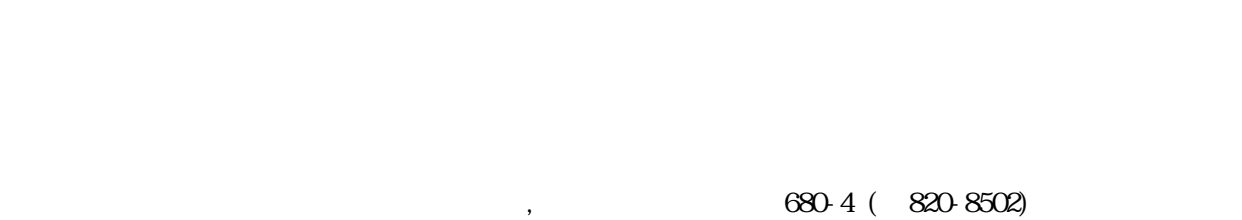

\section{1. まえがき}

有線通信システムにおいては, 通信線が電源供給線とし ても用いられることが多い1).従来の有線通信システムで は，Fig. 1 に示すように，端末で消費する全ての電力を主 電源から供給する ${ }^{2)}$. 主電源が故障した場合や保守作業の ために主電源を動作停止させた場合, システム全体がダウ ンする. 予め端末の数を想定して主電源の電力容量を決め る必要があり，しかも端末増設時にはシステムダウンを避 けるため更に大きな容量の電源と交換しなければならない 場合も起こり得る . 従って , 信頼度およびアベイラビリテ イが低く，保守作業を行いにくい.

このような欠点を解決するために，筆者らは, Fig.2 に示
すような新方式有線通信システムを提案した ${ }^{3)}$.給電端末 に小容量の電源装置を搭載し，これらを並列接続して給電 システムを構成する . システム全体の電源容量について供 給可能な電力の合計を全消費電力よりも大きく選んで余裕 を持たせると，並列冗長システムを実現できる.少数の給 電端末が故障してもシステムダウンに繋がらず，保守作業 時は端末を順次動作停止させることでシステムとして連続 運用可能である.端末を増設する場合は, 受電端末の数が 増えると共に給電端末の数を増やせば, 電力不足によるシ ステムダウンの心配が無くなる．

従来の有線通信システムでは, 主電源の電力容量が大き くなる傾向がある . 大容量電源は, 直流出力端子側すなわ ち通信線側に，リプルを抑制するための大容量コンデンサ やノイズを抑制するための高周波特性に優れたコンデンサ

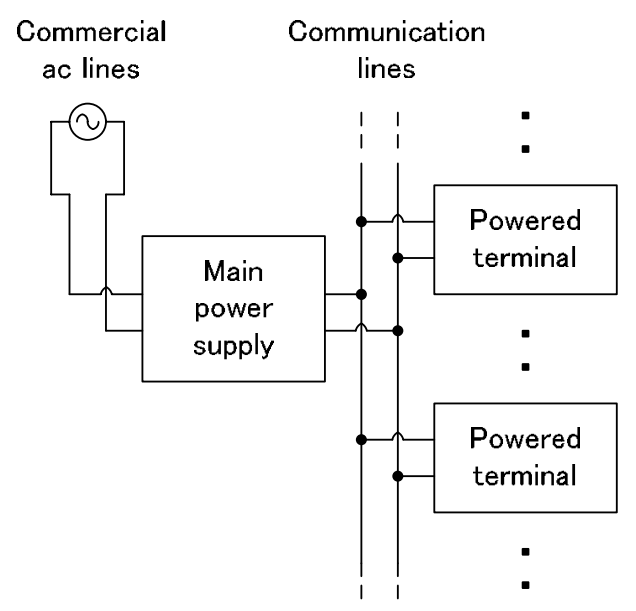

Fig. 1 Conventional wire communication system.

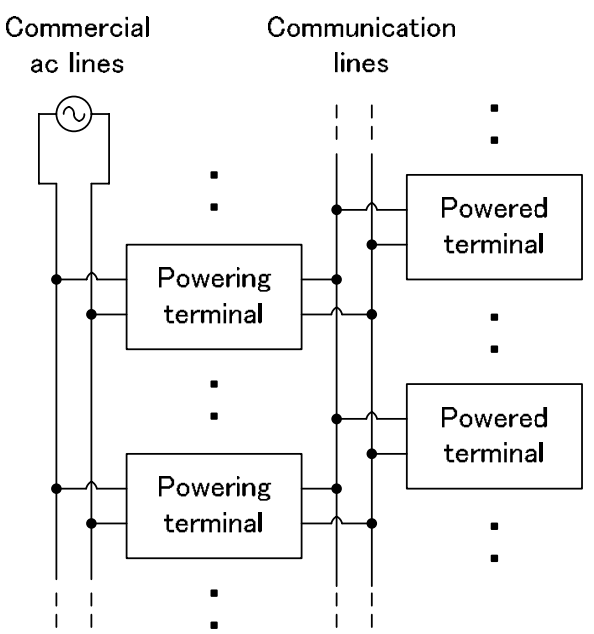

Fig. 2 Proposed wire communication system. 
を内蔵している . これらのコンデンサは通信信号に対して 極めて低いインピーダンスを示すため，兴の対策として主 電源と通信線との間にチョークコイルが設置される ${ }^{4)}$. 通 信信号の最低埖波数が低い場合や電源の直流出力電流が大 きい場合は, チョークコイルが大型化するという問題があ る。

乥こで，チョークコイルを除去することを目的として， 電子チョーク回路 ${ }^{5,6)}$ が考案された . この回路は, 能動状態 にあるベース接地トランジスタの出カインピーダンスが高 くなることを利用している．しかし，直流電流の向きが一 方向に制限され，また直流電流が大きい場合には電力損が 増大するという欠点がある．電子チョーク回路は，端末の 入力回路としても有用である . 但し, 主電源とは直流電流 の向きが逆になるため, トランジスタの極性を変更する必 要がある.

新方式有線通信システムでは, 直流電流の向きが双方向 性の電子チョークがあると，給電端末と受電端末とに同一 の回路を使うことができて便利である . 主電源を除去し , 電源を分散化したため, 電子チョークを流れる直流電流は 小さくなっている.この場合, 直流電圧調整は, 複数の出 力電圧が必要な場合も想定されるので, 別に回路を設けて 行うほうが合理的である．これらを考慮に入れて，小型の コイルと増幅器とを組み合わせることによって, 低電力損
の電子チョークを提案し, 動作や特性について既に報告し た ${ }^{7-13)}$.これらの回路は, コイルや増幅器の数が少ないな どの特長を有する .

本論文では, 小型コイルを用いる電子チョークの利点を 生かしつつ設計を容易にすることを目的として，ユニット 化した高入カインピーダンス・バッファと信号キャンセラ とを縦続接続して電子チョークを構成する方法を，提案す る。

\section{2. 通信用端末}

端末の構成例と光の動作説明図を，給電端末については Fig. 3 に,受電端末については Fig. 4 に示す.給電端末は, 商用交流から電源を受け取り通信線に送り出す．これに対 し，受電端末は，通信線から電源を受け取る . スイッチは 端末の動作状態を切り替えるものであり，“T”は送信を，"R” は受信を表す .”DC”または”AC”と書かれた矢印は，乥れぞ れ直流電源電力供給の向き, 交流通信信号伝達の向きを示 す . 待機状態では, 全ての端末は受信状態となり通信信号 を待っている . 通信を行う際には, 一つの端末が送信状態 となり，他の端末は受信状態のままである．送信状態の端 末は, 送信中の信号を关の端末の受信器で監視できる.

給電端末, 受電端末のいずれも, 電子チョークを持って

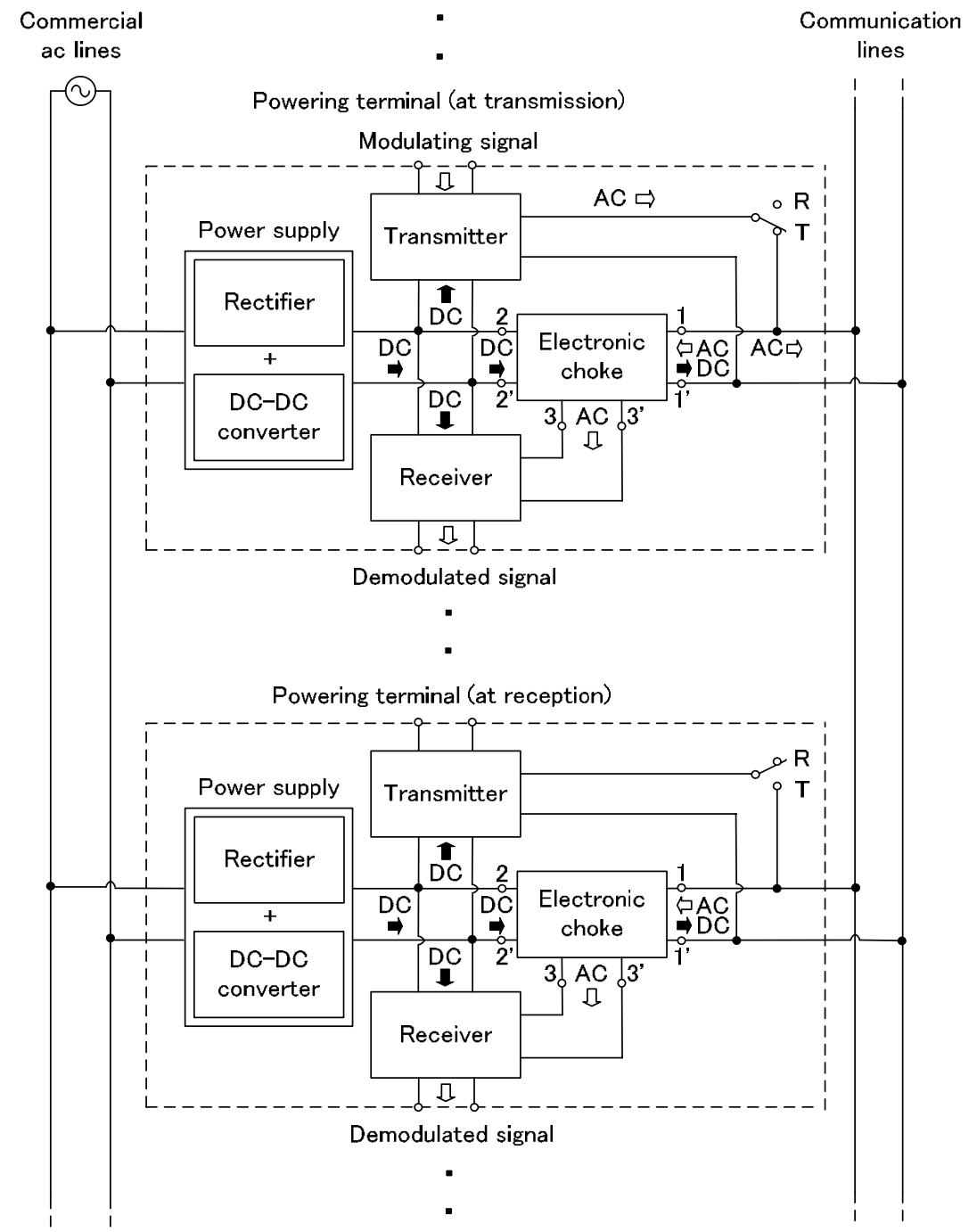

Fig. 3 Operation of powering terminals. 


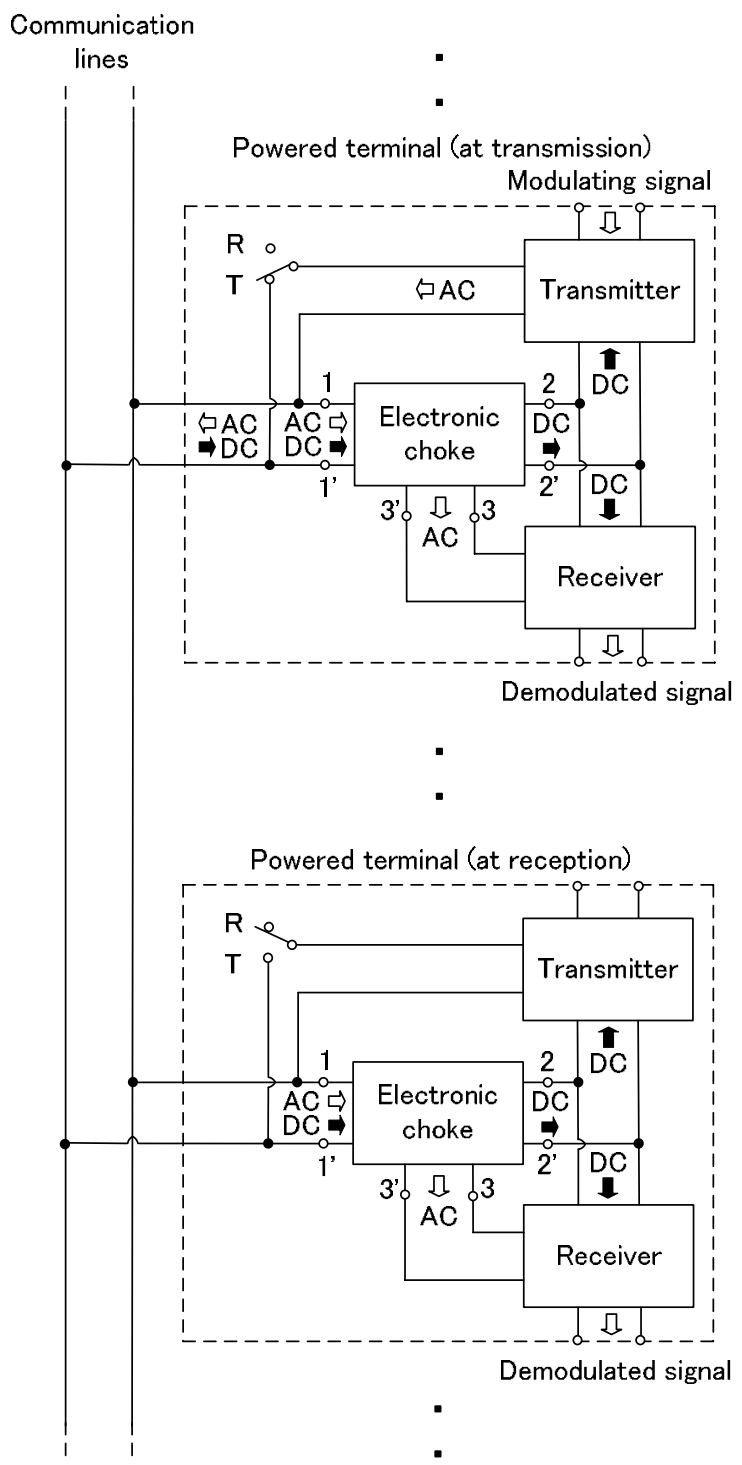

Fig. 4 Operation of powered terminals.

いる.給電端末では, 端子 2-2'間から直流電源電圧を印加 して端子 1-1'間から取り出し, 同時に端子 1-1'間から交流 信号電圧を印加して端子 3-3”間から取り出す．受電端末で は, 端子 1-1'間に直流電源電圧と交流信号電圧とを重畳し て印加して，端子 2-2'間から直流電源電圧を，端子 3-3'間 から交流信号電圧を, 分離して取り出すことができる．

\section{3. 電子チョーク}

提案する電子チョークの基本回路を, Fig. 5 に示す.上 側の部分が高入カインピーダンス・バッファであり，下側 の部分が信号キャンセラである . 直流電流は, 端子 1-2 間 を双方向に通過できる.インダクタ $\mathrm{L}_{1}, \mathrm{~L}_{2}$ の巻線抵抗を低 くすれば，電源電流による電力損を少なくできる．

交流信号に対する回路動作の概略は, 次の通りである . 増幅器 $\mathrm{A}_{1}$ の電圧利得 $A_{1}$ が 1 , 増幅器 $\mathrm{A}_{2}$ の電圧利得 $A_{2}$ が - 1 であるとする. 交流信号に対してコンデンサ $\mathrm{C}_{1}, \mathrm{C}_{2}$ ，

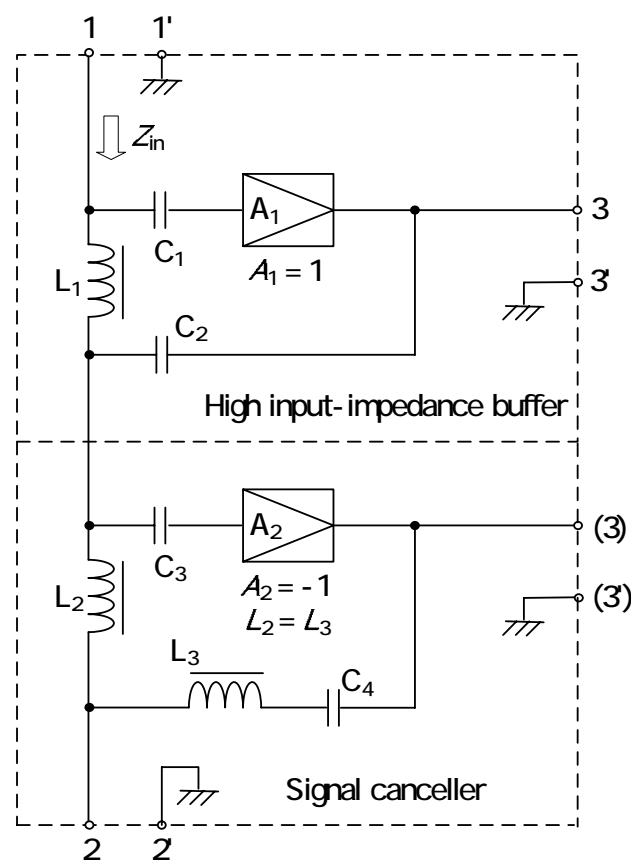

1-1': AC input and DC input (or output) $2-2$ ' : DC output (or input) 3-3' : AC output

Fig. 5 Basic circuit of new electronic choke.

$\mathrm{C}_{3}$,および $\mathrm{C}_{4}$ が十分低いインピーダンスを示すものとする と，端子 1-1'間に印加された交流信号電圧は，ブートスト ラップ効果によってインダクタ $\mathrm{L}_{1}$ の端子間には現れない . $\mathrm{L}_{1}$ に交流電流が流れないので，端子 1-1'から見た電子チョ 一クの (すなわち, 高入力インピーダンス・バッファの) 入力インピーダンス $Z_{\text {in }}$ は, 増幅器 $\mathrm{A}_{1}$ の入力インピーダン スによって決まる。

次に , 信号キャンセラにおいては, インダクタ $\mathrm{L}_{2}$ と $\mathrm{L}_{3}$ のインピーダンスを等しくする.この場合，端子 2-2'に接 続される負荷のインピーダンスにかかわらず, 負荷に信号 電圧は現れない，通信信号は, 端子 3-3’から取り出せる. 位相が反転した信号が必要ならば,増幅器 $\mathrm{A}_{2}$ 側から取り出 すこともできる .

\section{4. 解析}

解析に当たり，Fig. 6 に示す等価回路を用いた .コンデ ンサ $\mathrm{C}_{1}$ および $\mathrm{C}_{3}$ のインピーダンスは关れ光れ増幅器 $\mathrm{A}_{1}$, $\mathrm{A}_{2}$ の入力インピーダンスに比べて小さく無視できるもの として，簡単のため，これらを０とした．

バッファの入カインピーダンス $Z_{\text {in }}$ は, 増幅器 $\mathrm{A}_{1}$ の入力 インピーダンス $Z_{\mathrm{i} 1}$ およびインダクタ $\mathrm{L}_{1}$ 側をみたインピー ダンス $Z_{\mathrm{i} 3}$ の並列インピーダンスとなる.従って , Fig. 6 か ら , 次に示す関係式が得られる .

$$
Z_{\text {in }}=\frac{Z_{\mathrm{i} 1} Z_{\mathrm{i} 3}}{Z_{\mathrm{i} 1}+Z_{\mathrm{i} 3}}
$$




$$
Z_{\mathrm{i} 3}=\frac{1+\left(Z_{4}+Z_{\mathrm{o} 1}\right)\left(\frac{1}{Z_{1}}+\frac{1}{Z_{\mathrm{ic}}}\right)}{1-A_{1}+\frac{Z_{4}+Z_{\mathrm{o} 1}}{Z_{\mathrm{ic}}}} Z_{1}
$$

ここで, $A_{1}$ は増幅器 $\mathrm{A}_{1}$ の電圧利得, $Z_{01}$ は $\mathrm{A}_{1}$ の出カイン ピーダンス，Z1 $Z_{1}$ はインダクタ $\mathrm{L}_{1}$ のインピーダンス ,および $Z_{4}$ はコンデンサ $\mathrm{C}_{2}$ を含む帰還回路のインピーダンスであ る。

信号キャンセラの入カインピーダンス $Z_{\mathrm{ic}}$ は, 増幅器 $\mathrm{A}_{2}$ の入カインピーダンス $Z_{\mathrm{i}}$ およびインダクタ $\mathrm{L}_{2}$ 側をみたイ ンピーダンス Z Zi4の並列インピーダンスとなるから，

$$
\begin{aligned}
& Z_{\mathrm{ic}}=\frac{Z_{\mathrm{i} 2} Z_{\mathrm{i} 4}}{Z_{\mathrm{i} 2}+Z_{\mathrm{i} 4}} \\
& Z_{\mathrm{i} 4}=\frac{1+\left(Z_{3}+Z_{\mathrm{o} 2}\right)\left(\frac{1}{Z_{2}}+\frac{1}{Z_{\mathrm{L}}}\right)}{1-A_{2}+\frac{Z_{3}+Z_{\mathrm{o} 2}}{Z_{\mathrm{L}}}} Z_{2}
\end{aligned}
$$$$
V_{2}=\frac{Z_{\mathrm{L}}}{Z_{\mathrm{oc}}+Z_{\mathrm{L}}} V_{\mathrm{oc}}
$$

$$
Z_{\mathrm{oc}}=\frac{Z_{2}\left(Z_{3}+Z_{\mathrm{o} 2}\right)}{Z_{2}+Z_{3}+Z_{\mathrm{o} 2}}
$$

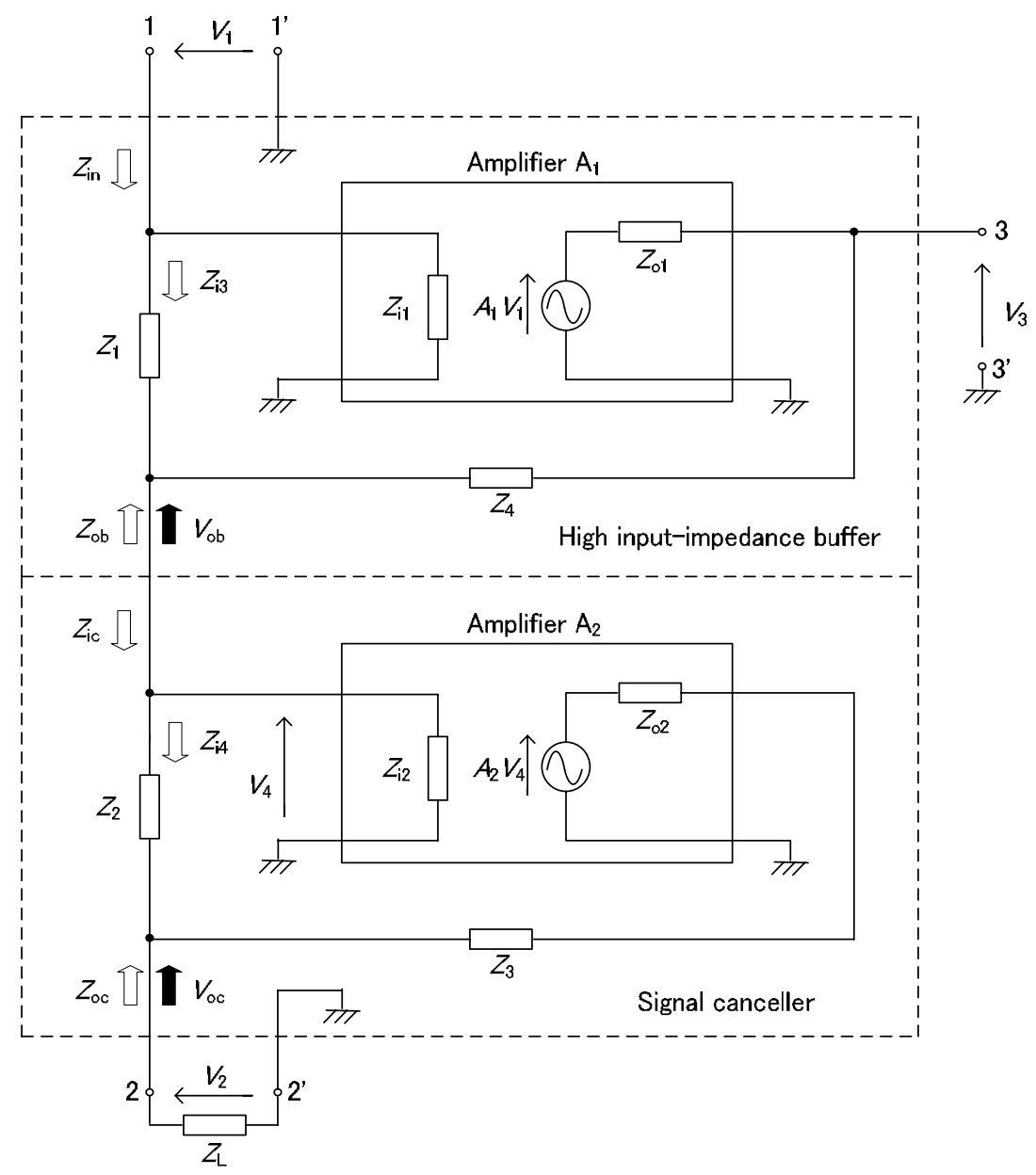

Fig. 6 Equivalent circuit for AC component. 
ここで, $V_{\mathrm{oc}}$ および $Z_{\mathrm{oc}}$ は, 信号キャンセラの出力開放電圧 （Z無限大時の出力電圧）および出力インピーダンスである . バッファの交流出力電圧 $V_{3}$ および信号キャンセラの交 流入力電圧(増幅器 $\mathrm{A}_{2}$ の入力電圧) $V_{4}$ は, 次式で与えられ る。

$$
\begin{aligned}
& V_{3}=\left\{1-\frac{\left(1-\frac{1}{A_{1}}+\frac{Z_{1}}{Z_{\mathrm{ic}}}\right) Z_{\mathrm{o} 1}}{Z_{1}+Z_{4}+Z_{\mathrm{o} 1}+\frac{Z_{1}\left(Z_{4}+Z_{\mathrm{o} 1}\right)}{Z_{\mathrm{ic}}}}\right\} A_{1} V_{1} \\
& V_{4}=\frac{Z_{\mathrm{ic}}}{Z_{\mathrm{ob}}+Z_{\mathrm{ic}}} V_{\mathrm{ob}} \\
& V_{\mathrm{ob}}=\frac{1+\frac{Z_{4}+Z_{\mathrm{o} 1}}{A_{1} Z_{1}}}{1+\frac{Z_{4}+Z_{\mathrm{o} 1}}{Z_{1}}} A_{1} V_{1} \\
& Z_{\mathrm{ob}}=\frac{\frac{Z_{1}\left(Z_{4}+Z_{\mathrm{o} 1}\right)}{Z_{1}+Z_{4}+Z_{\mathrm{o} 1}}}{}
\end{aligned}
$$

ここで， $V_{1}$ は端子 $1-1$ 間の交流入力電圧であり， $V_{\mathrm{ob}}$ およ び $Z_{\mathrm{ob}}$ はバッファの出力開放電圧 $\left(Z_{\mathrm{ic}}\right.$ 無限大時の出力電圧) および出カインピーダンスである .

Fig. 7 は, 計算結果のグラフを描くに際して用いた $Z_{1}$, $Z_{2}, Z_{3}, Z_{4}$, および $Z_{\mathrm{L}}$ の等価回路である.増幅器の電圧利 得 $A_{1}$ および $A_{2}$ については，これらを一次遅れ特性で近似 し, 直流電圧利得を光れ光れ $\left|A_{1}\right|_{\mathrm{DC}},\left|A_{2}\right|_{\mathrm{DC}}$, 高域遮断周波数

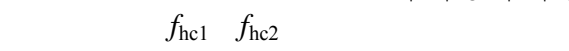

\section{5. 入力インピーダンス特性}

実験回路を Fig. 8 に示す. 信号周波数を $f$, 交流負荷抵 抗を $R_{\mathrm{L}}$, 直流負荷抵抗を $R_{\mathrm{DC}}$ で表している． $V_{\text {in }}$ は直流電 源電圧， $I_{0}$ は $R_{\mathrm{DC}}$ に流れる電流の直流分である. $\mathrm{RFC}$ は高 周波用チョークコイル，CH は低周波用チョークコイル， $\mathrm{C}_{\mathrm{C} 1}$ および $\mathrm{C}_{\mathrm{C} 2}$ は直流を阻止するための結合コンデンサを 表す .

入カインピーダンス $Z$ in の大きさ $\left|Z_{\text {in }}\right|$ について , 測定值 と計算値を比較したものを, Fig. 9 に示す. 測定結果と (1) (4)式から求めた計算結果とを比較すると，大体良く一 致していることが分かる .

\section{6. 交流電圧減衰特性}

端子 1-1'間に交流電圧 $V_{1}$ を印加すると，端子 2-2’に接続 された負荷 $\mathrm{R}_{\mathrm{L}}$ には，僅かではあるが交流電圧 $V_{2}$ が現れる . Fig. 10 に,端子 1-1' から端子 2-2' までの交流電圧減衰特性 を示す . $V_{2} / V_{1}$ は ,(5) (7)および(9) (11)式を用いて計算でき

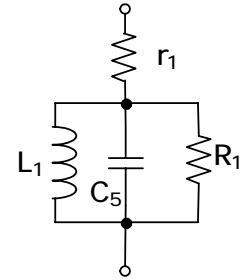

(a) $Z_{1}$

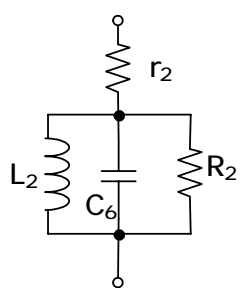

(b) $Z_{2}$

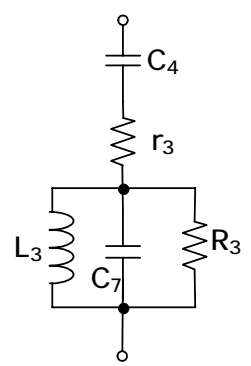

(c) $Z_{3}$

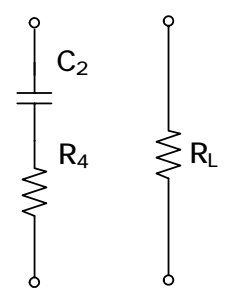

(d) $Z_{4}$

(e) $Z_{\mathrm{L}}$

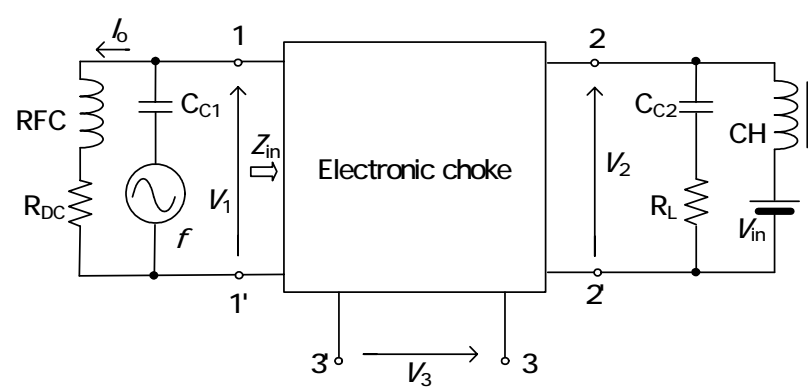

Fig. 8 Experimental circuit.

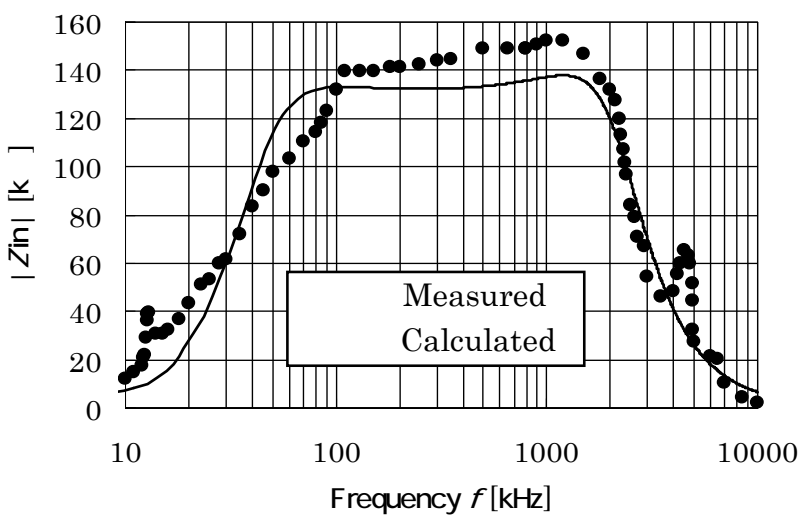

Fig. 9 Frequency characteristics of Input-impedance $Z_{\text {in }}$. 


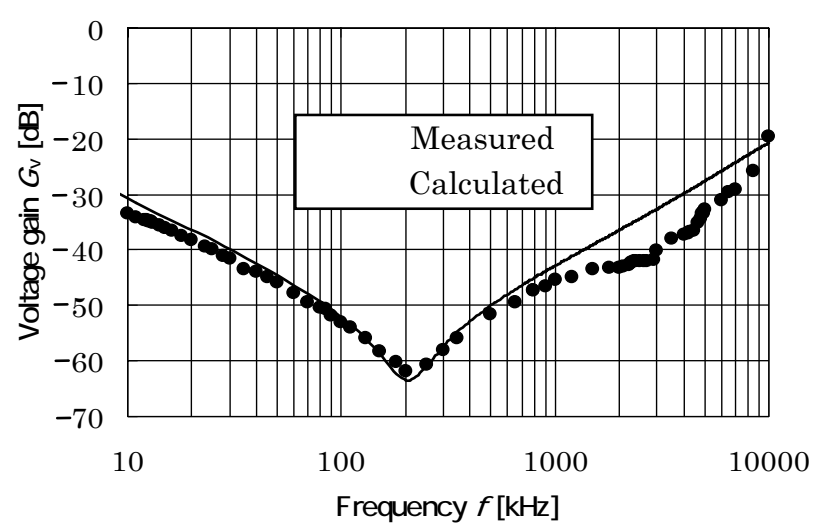

Fig. 10 AC component reduction ratio from 1-1' to 2-2'.

る.なお， $V_{2} / V_{1}$ の大きさを Fig. 10 に記載する際には , デ シベル表示 $G_{\mathrm{v}}$ を用いた .

提案した電子チョークでは， $\mathrm{L}_{2}$ と $\mathrm{L}_{3}$ によって交流電圧 が強制的に打ち消されるため, 端子 2-2'にフィルタ用コン デンサを接続しなくても，優れた減衰効果が得られること が分かる.

解析および実験に当たり，使用したパラメータの值は次 の通りである. $L_{1}=L_{2}=14 \mathrm{mH}, L_{3}=16 \mathrm{mH}, C_{2}=C_{4}=1 \mu \mathrm{F}$, $C_{5}=C_{6}=C_{7}=10 \mathrm{pF}, R_{1}=11 \mathrm{k} \Omega, R_{2}=R_{3}=2.5 \mathrm{k} \Omega, R_{4}=51 \Omega, R_{\mathrm{L}}=230$ $\Omega, r_{1}=r_{2}=r_{3}=5 \Omega, Z_{i 1}=200 \mathrm{k} \Omega, Z_{\mathrm{i} 2}=10 \mathrm{k} \Omega, Z_{01}=Z_{02}=70 \Omega$, $\left|A_{1}\right| \mathrm{DC}=1.02,\left|A_{2}\right|_{\mathrm{DC}}=-1.02$, h hc1 $_{\mathrm{h} 1}=50 \mathrm{MHz},,_{\mathrm{hc} 2}=10 \mathrm{MHz}$, $V_{\mathrm{in}}=26 \mathrm{~V}, I_{0}=0.1 \mathrm{~A}$.なお， $\mathrm{L}_{1}, \mathrm{~L}_{2}$ ，および $\mathrm{L}_{3}$ には，同一 サイズのフェライト磁心(幅 $13 \mathrm{~mm}$, 高さ $8 \mathrm{~mm}$, 奥行き $12 \mathrm{~mm})$ を用いた .

\section{7. むすび}

新しい電子チョークを提案し, 入カインピーダンス特性 および交流電圧減衰特性を調べた。光の結果，優れた特性 が得られることが, 実験によって確かめられた . 高入力イ ンピーダンス・バッファは,ブートストラップ動作を行い， 比較的広い周波数範囲で安定した高入カインピーダンス特 性を得ている . 信号キャンセラは, 逆相増幅器と二個のイ ンダクタを用いて交流電圧の打ち消し回路を構成した点に
特徵がある . 通常の低域通過フィルタとは異なり, フィル タ・コンデンサを使用せずに, 交流電圧を十分に減衰させ ることができる

解析に際しては，磁心の損失等を考慮した等価回路を用 いて特性を算出した . バッファと信号キャンセラが縦続接 続されていることを念頭に置きながら，信号キャンセラの 入カインピーダンスがバッファの負荷インピーダンスに , バッファの出カインピーダンスが信号キャンセラの信号源 インピーダンスになるという，互いの影響を考慮しつつ見 通しの良い解析式を得ることを心掛けた，弚の結果，測定 結果と計算結果とが良好に一致することを確認した。

今後は，通信信号の波形や周波数スペクトルなどを考慮 に入れた最適設計，およびノイズ対策として電子チョーク の平衡化を検討したいと考えている.

\section{References}

1) P. H. Sutterlin, W. R. Bemiss, and G. M. Hey: US Patent, 5148144 (1992).

2) Y. Nagata: Tokkyo Koho, 1144477 (1982).

3) A. Katsuki, M. Matsushima, and N. Takimoto: Proc. INTELEC 1999, Copenhagen, 1999, Paper No. 13-1 (IEEE, Piscataway, 1999).

4) H. Ott and H. Zierhut: EU Patent, 365696B1 (1995).

5) J. Pest: US Patent, 3649769 (1972).

6) S. Nojima, N. Ooba, K. Yamamoto: Tokkyo Koho, 2079176 (1995).

7) A. Katsuki, T. Matsumoto, T. Eto, and Y. Hashimoto: Proc. INTELEC 2003, Yokohama, 2003, p. 615 (IEEE, Piscataway, 2003).

8) A. Katsuki and T. Matsumoto: J. Magn. Soc. Jpn., 28, 620 (2004).

9) A. Katsuki and T. Matsumoto: Proc. INTELEC 2004, Chicago, 2004, p. 482 (IEEE, Piscataway, 2004).

10) T. Matsumoto and A. Katsuki: J. Magn. Soc. Jpn., 29, 170 (2005).

11) A. Katsuki, S. Watanabe, T. Matsumoto, and M. Fukunaga: Proc. INTELEC 2005, Berlin, 2005, p. 77 (IEEE, Piscataway, 2005).

12) A. Katsuki, T. Matsumoto, S. Watanabe, and M. Fukunaga: IEEJ Trans. IA, 126, 904 (2006).

13) A. Katsuki, M. Matsushima, K. Matsunaga, and K. Morisaki: Proc. PCC 2007, Nagoya, 2007, p. 1412 (IEEE, Piscataway, 2007).

2007年11月29日受理，2008年3月14日採録 